\title{
What are banks and bank regulation for? A consideration of the foundations for reform
}

\author{
Sheila C. Dow*
}

\begin{abstract}
The paper considers the different ways in which we can approach reform of banking regulation by reflecting on different views on the nature and purpose of money and banks. We consider first the mainstream theory of banking and the interpretation of moral hazard as an expression of calculative rational behaviour, such that reform of banking regulation is formulated in terms of financial incentives and constraints. Post-Keynesian banking theory rather emphasises banks' role in providing society's money and thus the centrality of social conventions, particularly confidence in the money asset. The key is to design regulation so as to allow banks to play their supportive role in the economy, while suppressing scope for a negative role. This approach involves a broader understanding both of moral hazard and of regulation itself.
\end{abstract}

JEL classifications: B50, E42, G28

Keywords: banking functionality, philosophical foundations of banking regulation, moral hazard

\section{Introduction}

The financial crisis has prompted extensive, and at times radical, discussion of banking regulation. While this is a welcome development, there has been little reflection on the nature of regulation in terms of the functionality of the banking sector in relation to society.

* University of Stirling, UK. This paper has benefited from discussion following presentation of an earlier version of this paper to the FMM Conference, Berlin October 20Io, and the Post Keynesian Economics Study Group, Cambridge November 20Io, from discussions with Victoria Chick and Peter Hughes, and from comments from Jörg Bibow and two anonymous referees.

Correspondence Address:

Prof. Sheila C. Dow, SCEME, Division of Economics, University of Stirling, Stirling FK9 4LA, UK, e-mail: s.c.dow@stir.ac.uk.

Received 3I January 20II, accepted I7 May 20II

(C) INTERVENTION 9 (I), 20I2, 39-56 
Yet the way in which regulation is discussed inevitably reflects the underlying approach, not just at the level of theory but also at the level of philosophy. Without explicit reference to such foundations the ensuing debate is inevitably limited and potentially confused. The purpose of this paper is to attempt to make up for that lack by exploring how differently regulation is viewed between the mainstream approach, which is dominating the terms of debate, and the post-Keynesian approach. The comparison will be given focus by considering their different understandings of moral hazard, a central concept in current discussions about reform of banking regulation. There is an immense and sophisticated literature on the content of regulatory reform, a highly complex topic. But the emphasis of the discussion here is on approach to regulation rather than the detail of regulation itself.

Moral hazard was chosen as the focus because the smoral aspect of the concept involves such ambiguities and yet becomes clear when seen against different philosophical backgrounds. Much of the public reaction to the banking crisis and the ensuing economic crisis has been one of moral outrage. This is expressed in relation to the behaviour and treatment of individuals, but also in relation to wider social issues about the contribution of the banking sector to society and about society-wide income distribution. But ever since the marginalist revolution questions of morals have been deliberately excluded from mainstream economic discourse as not being the concern of economists. This follows from the view that economics is a positive science. Akerlof and Shiller (2009) have recently departed from this approach by bringing the moral concept of fairness into the discourse. Nevertheless they maintain the customary strict division between rationality and morals.

Yet at the centre of the mainstream analysis of the crisis has been the concept of moral hazard. The acceptance by banks of undue risk was seen as a consequence of the historical experience of central banks supporting the banking system in order to prevent crisis. The support given again in the current crisis reinforces this moral hazard, sowing the seeds of the next crisis. This mainstream framework presumes rational behaviour which, in the context of moral hazard, is opportunistic. But is it immoral? The ambiguity of moral hazard as a concept arises from the possibility that it can be captured as rational behaviour. This discourse is coloured by mainstream methodological individualism, whereby economic behaviour is understood in terms of rational calculation and issues of morals are effectively considered in terms of individual preferences. As we argue in what follows, moral hazard in mainstream theory has nothing much to do with morals as generally understood, so that their use of the term $>$ moral has simply confused the public discourse on the crisis (see further Dow forthcoming).

But non-mainstream approaches such as post-Keynesian economics keep alive the Classical view of economics as a moral science by focusing on the moral aspect of social structures, i.e. on interdependency. Consideration at this level focuses attention on how far the various parties recognise and honour their interdependence. This focus in turn accords with the social-conventional aspects of knowledge under uncertainty and the socialconventional nature of confidence in banks and in bank deposits as money which characterise post-Keynesian theory of money and banking. It also accords with the post-Keynesian focus on how far the banking sector is functional, i.e. serves its social purpose. As we shall argue, 
moral hazard and the policies to address it take on a much wider meaning in a post-Keynesian analysis of reform of banking regulation than in the mainstream approach.

In what follows therefore we consider the different (mainstream and post-Keynesian) approaches to understanding money and banking and banking regulation in general, to demonstrate how each reflects a different understanding of the functioning and functionality of banking, of the economy and ultimately of society and human nature. Narrow and broad understandings of moral hazard are then seen to be addressed with narrow and broad understandings of banking regulation, respectively. There is a corresponding difference in emphasis between an individualistic rationalist understanding of moral hazard on the one hand and hazards with respect to social systems on the other. The choice is between the relative emphasis placed on incentives and constraints and the stability of social structures, respectively.

\section{Mainstream approach to reform of banking regulation}

The mainstream approach to reform of banking regulation is conditioned by the way in which banks are understood theoretically. Banking theory as such is somewhat limited in mainstream economics. At the macro level money and the interest rate have traditionally been analysed by means of abstracting from banks. Banking theory is therefore a particular application, at the micro level, of the theory of the firm, such that banks are understood as firms maximising profits subject to constraints. Further, banks are understood as no more than financial intermediaries, redirecting savings to finance investment. As Merton (1993: 20) states:

"A well developed smoothly functioning financial system facilitates the efficient lifecycle allocation of household consumption and the efficient allocation of physical capital to its most productive use in the business sector".

Welfare is enhanced by competitive market forces ensuring the lowest marginal cost of providing these services at an optimal level. From this perspective the role of regulation is to promote these market forces. Yet, since banks are seen as firms like any other, some argue that there is no special case for regulation other than conventional company regulation (see for example Gowland i990).

In spite of the process of deregulation initiated in the I980s, the financial sector is still segmented to some extent. In particular banks are seen still to differ from other financial intermediaries within the mainstream framework (see for example de Bondt's 2000: ch.I, review). This difference stems from the distinctive regulation of banks over a long period which promoted asymmetries in transaction costs and information. Traditionally regulation segmented the financial sector such that banks dominated the deposit and credit markets. Through close knowledge of their depositors, banks developed information advantages over other credit suppliers when it came to risk assessment of credit applicants. This allowed banks to undertake non-marketed loan contracts, priced according to reliable assessment of default 
risk. While banks were required by regulation or convention to hold only certain proportions of liquid assets, their liabilities were predominantly highly liquid. This differentiated banks from other financial intermediaries, which had to take care to match any such illiquid assets with illiquid liabilities.

This maturity mismatch for banks compared to other financial intermediaries was supported not just by informational advantages, but also by the relationship with the central bank, whereby the lender-of-last-resort facility ensured that banks need not face the consequences of undue default risk on the part of their borrowers. But this is identified as creating the moral hazard that banks took on more risk than they would have done without such protection. Suboptimal amounts of credit expansion were thus encouraged. Free bankers have long identified this moral hazard, protecting banks from market discipline, as a primary source of banking crises (Dowd 2009). Without this protection, markets would rationally calculate the risk profile of banks and allocate funds accordingly. The incentive would be created, which is currently absent, for banks to attract deposits by means of a favourable assessment of their portfolio risk. There is no role for systemic risk from this perspective. Rather, excessive risk is seen as arising at the micro level for individual institutions and financial resources (within a financial intermediation conceptual framework) are allocated accordingly.

Indeed the starting position is that market forces produce the socially-optimal outcome, ceteris paribus. Free Bankers and New Monetary Economists therefore take the extreme position that the state should minimise its involvement in banking altogether (see for example Dowd 2009, Cowen/Kroszner 1987, respectively). While this is the logical outcome of mainstream banking theory, the more widespread traditional neoclassical view was more moderate, that the state should reduce rather than eliminate special financial regulation, in particular regulatory differentiation between financial institutions. This was the basis for financial deregulation led by the USA and the UK in the I970s and I980s, and the financial liberalisation policies promoted by what became dubbed the Washington Consensus. Following the South-East Asia crisis which many attributed to that same liberalisation policy, the emphasis in Washington changed somewhat to a focus on governance in borrowing countries, including practices with respect to bank regulation and supervision (see Dow 2008). Similar concerns with governance have arisen in the current crisis.

The most influential theoretical analysis both of the South-East Asia crisis and the current crisis has identified market imperfections as the root cause of these problems (see for example Calomiris 1998 and 2009, respectively). This New Keynesian analysis emphasises the particular role of information asymmetries and perverse incentives which have distorted market forces. They therefore see a positive role for regulation in addressing market imperfections. Many of these arise from particular practices and institutional arrangements in the financial sector itself. The current detailed discussion of financial sector reform stems from the particular governance issues identified in relation to markets in structured products, the role of credit rating agencies, the structure of bank bonus systems, and so on. The aim remains to ensure that markets operate more effectively. 
Pride of place in the New Keynesian analysis of the banking crisis is given to the market imperfection of the central bank lender-of-last-resort facility, which created moral hazard, undermining market forces. The term 'moral hazard is a curious one to find in mainstream discourse. ${ }^{I}$ When it originated in the insurance literature, there was an element of moral judgment involved in considering the insured taking on more risk as a result of insurance. Indeed, Arrow's (1963) pioneering article applying the concept to medical insurance focused on the ethical problem of consultants recommending inappropriate levels of treatment because of medical insurance. The problem was compounded by the uncertainty facing the patient about the nature of the problem and the appropriate treatment. The solution lay in professional bodies promoting ethical behaviour.

But as the notion of moral hazard entered into mainstream decision theory, it was explicitly concluded that behaviour under moral hazard reflected the rational pursuit of self interest; to advocate other behaviour would be to advocate irrationality (Pauly 1968: 535). Thus the credit rationing literature does not purport to make any moral judgment about borrowers concealing information from banks; the presumption is that this behaviour is rational. Further, the context has moved away from Arrow's context of uncertainty. Borrowers are presumed to know their own default risk but to behave opportunistically (i.e. rationally) with respect to the banks. Banks' uncertainty then refers to objective risk measures which are concealed from them. ${ }^{2}$ In a similar vein the mainstream theoretical discussion of excessive risk-taking by banks as the unintended consequence of the lender-of-last-resort facility makes no apparent moral judgment, but rather considers bank behaviour as a rational response to central bank support. The solution to this moral hazard problem is therefore not to discourage rational behaviour but rather to address the market imperfections which created the problem. The use of the term >morak is thus misleading.

Insofar as market imperfections are understood to be inevitable, so that some form of special regulation of the financial sector is necessary, the leading set of ideas refers to minimum capital requirements (based on quantitative estimates of default risk) and other possible limitations on asset structure. Another set of ideas for regulatory reform focuses on restoring some segmentation, such that central bank protection applies only to banking in its traditional form, dubbed sutility banking by the governor of the Bank of England (King 2009). This retail banking, split off from investment banking, or at least with a prohibition on proprietary trading, would directly limit the opportunities for excessive risk-taking. Another set of proposals focuses on reducing the incentives for excessive risk-taking. These refer to the structure of rewards within banking institutions.

As far as moral hazard is concerned however the lender-of-last-resort facility is seen as the most significant distortion, encouraging excessive risk-taking. The issue is widely identified as the stoo-big-to-failı, or the stoo-important-to-fail p problem, such that the central bank (supported by the state) has no choice but to support large banks facing liquidity and solvency problems. This is explained either in terms of the political power of large institutions, or the

I See Dembe and Boden (2000) and Dow (forthcoming) for a more full discussion. 
systemic risk that failure of such an institution can cause the system, through the domino effect of defaults running through interconnected portfolios. Segmentation of retail banking is thus justified, not only in terms of reducing opportunities for taking on excessive risk, but also in terms of size or importance. As King (2009: 4) argued, the options for regulatory reform fall into only two categories.

"One is to accept that some institutions are stoo important to fail and try to ensure that the probability of those institutions failing, and hence of the need for taxpayer support, is extremely low. The other is to find a way that institutions can fail without imposing unacceptable costs on the rest of society« (emphasis added).

A key goal is to restore confidence in the banking system. In mainstream economics, confidence is the outcome of rational calculation (see Hughes 20II). The proposals outlined above involve new inputs to such calculation. Higher capital and liquidity ratios, restrictions on high-risk activities and reduced incentives to take on high risk, together with the enhanced deposit insurance schemes which were part of the immediate response to the crisis, should all reduce the rational calculation of risk attached to banks and thus enhance confidence. These all amount to a significant change.

Set against this is the higher expectation of risk of bank failure because of the avowed intent of central banks to countenance bank failure much more readily than in the past. Deposit insurance provides protection up to a point, but with time lags and uncertainties which would reduce the acceptability of bank deposits as means of payment. Further, without the lender-of-last-resort facility, it is not at all clear that rational calculation would indicate that fractional reserve banking, even with the regulatory restrictions outlined above, would justify deposits. Banks alone have evolved with significantly mismatched maturities on their balance sheets which in part reflected central bank support, but also pre-dated it. Without that support, banks' maturity structure would have to change drastically so that it was rational to continue placing deposits with banks.

This argument explains the attention now being given to a form of narrow banking which eschews fractional reserves (and thus banking) altogether (see for example Kotlikoff 20IO). ${ }^{3}$ It therefore seems that removal of the lender-of-last-resort facility in order to address moral hazard, within a framework where both banks and their customers make decisions on the basis of rational calculation, is incompatible with the continuation of banking as traditionally understood, i.e. the >originate-and-hold model. If even traditional banking is to disappear, we have to return to the question of what banks and bank regulation are for.

3 Some applications of the term snarrow banking allow for a range of possible asset structures, including the possibility of business lending (see for example Kay 2009). 


\section{Post-Keynesian approach to reform of banking regulation}

\section{I Post-Keynesian theory of banking}

There are other ways of understanding banking, and indeed the economy more generally, which lead to a rather different discourse on moral hazard and its solutions in reform of banking regulation. The following account of such an alternative, the post-Keynesian theory of banking, draws heavily on Chick's (1986) theory of banking development framework. ${ }^{4}$ This theory traces the increasing functionality of banking in terms of providing both a means of payment and the consequent capacity to create credit (and thus promote growth) in the early stages of banking development and the emergence in later stages of forces which threatened that functionality.

According to Chick's analysis, banking originally developed as confidence grew in the capacity of bankers to honour their liabilities. As these liabilities came to be more widely accepted as a means of payment, bank notes and then title to bank deposits came to take on the attributes of money along with specie. Together these different forms of money, as an institution, provided the foundation for capitalism (see Dillard 1987). Further, bank deposits' role as money is the outcome of a conventional social relation (see Ingham 2004). This role for deposits was reinforced by habitual practices and by historical experience which encouraged a socio-psychological state of confidence in banks. Banks were thus increasingly providing money alongside the state. The state effectively came to treat banks as agents in the provision of society's money and thus took a particular interest in the banks' continued capacity to do so, since any experience of bank failure threatened the confidence held in the banking system as a whole.

The role of central banks therefore evolved to take on responsibility for the stability of the private sector banking system, first providing liquidity in response to crises and later making an undertaking in advance that this would be the case in any future crisis, the lenderof-last-resort facility. This facility was addressed to the possibility of systemic risk as much as to the risks facing any one bank. This systemic risk arose partly from the interconnectedness of bank portfolios, particularly through the interbank market, which could spread the effects of the failure of one bank to others. But the policy was also addressed to systemic risk that contagion could spread a loss of confidence in one bank to other banks in the system. The scope for contagion in downward revisions in market valuations of banks' assets arises from the absence of the basis for a fully objective valuation, hence the significance of market sentiment. In return banks were subject to special regulation, supervision and monitoring to reduce the need for recourse to the lender-of-last-resort facility.

This central bank policy encouraged increasing confidence in banks and their liabilities which allowed banks increasing capacity to expand credit with reduced reserve ratios; indeed since reserves were now endogenous the banks could now effectively decide on their credit levels and thus the level of deposits and thus money. Unlike other financial 
institutions therefore banks were not just financial intermediaries but also credit, and thus money, creators. Monetary policy now took the form of the setting of an official interest rate, providing another important public policy influence on banking profitability and behaviour apart from banking regulation and supervision. While the lender-of-last-resort facility referred to crisis borrowing which has occurred only rarely, in practice the need for it has generally been obviated by the central bank mechanism for enforcing the official interest rate, which is to manage market liquidity on a day-to-day basis.

Up to this stage in banking development, banking became increasingly functional, in Studart's (1995) sense of meeting the needs of the economy for a means of payment and for credit to finance investment in advance of saving, where credit is sustainable in the sense of most being repaid. But the greater freedom to create credit which resulted from the central bank's undertaking to provide liquidity allowed the banks to shift their focus from meeting clients' needs to meeting their own needs to maintain market share and enhance profits. This was achieved by liability management which involved banks' increasing dependence on the interbank market. This supported an expansion of credit beyond the real economy's needs by financing speculation. As central banks responded with new capital adequacy regimes of bank regulation, banks developed strategies to minimise the burden these requirements posed. Their new business models included securitising loans and increased engagement in derivatives markets, developments which ultimately led to the current crisis. The banking system was no longer functional. And yet the mainstream argument that it was welfareenhancing supported the efforts of banks to encourage governments to engage in a process of deregulation which allowed even more scope for the banks' destabilising activities.

The development of banking is thus bedevilled by a series of tensions which have to be kept in some balance in order to promote stability and functionality, which themselves are interdependent. First, there is a tension between competition between banks and cooperation. Chick (1987) shows how competing banks early on addressed their vulnerability to reserve drains by cooperating in the interbank market. This mechanism for smoothing out the effects of interbank settlements with countervailing interbank loans increased the stability of the system, to the benefit of all. Yet, with deregulation which reduced market segmentation, the balance shifted in favour of increased competition between banks and it was the freezing of the interbank market which was the turning-point in the onset of the banking crisis. This was an expression of >liquidity hoarding ' on the part of banks, in line with a more general increase in liquidity preference in other sectors due to the crisis (Bibow 2009).

There is a second tension with respect to competition itself. Banking history demonstrates the tendency for the banking sector to concentrate; this process is evident in the wake of any change in the environment which opens up the market and encourages new entry. This is a natural consequence of the need for banks to inspire confidence. When there is any doubt about the viability of new banks, there is a tendency for business to return to large old banks, reducing the competitiveness of the sector again. There is therefore a tension between large banks, promoting confidence in the system, and the stoo-big-to-fail issue which arises from the market and political power of very large banks. 
There is a further series of tensions, between the banks and the central bank. Central bank regulation with the lender-of-last-resort facility at the core had succeeded in ensuring a stable banking system by increasing confidence in banks. But the same regulation threatened the stability of the banking system to the extent that it increased the latitude for banks to create credit irrespective of the economy's needs, fuelling speculative asset markets. This creditcreating capacity increased as banking evolved, with the reduction in reserve ratios which was in turn justified by the increase in confidence in banks which sustained the redeposit ratio, thus reducing the risk of reserve drain. In fact, as the supply of reserves became endogenous as a by-product of central banks' market interventions to enforce the official rate, the size of reserve ratio became unimportant. Indeed it was reduced to miniscule levels, with the function of reserves being reduced to settlement requirements. Confidence in banks was such that the size of reserves seemed unimportant. But paradoxically the demise of serious reserve ratios also made the banks more vulnerable.

Indeed a fractional reserve banking system is inherently vulnerable; it is stable only if confidence in the banks' liabilities is maintained. Banks are at their most vulnerable when the financial system is at its most fragile, as explained by Minsky (1982 and 1986). Banks themselves are vulnerable to a shift in the socio-psychological state of confidence; a major downward shift can, as we have seen, cause a banking crisis. Even if rational calculation in the mainstream sense were feasible, it would not justify confidence in fractional reserve banking unless there was an understanding that central banks would always protect the banking system. Hence the need for the principal/agent relationship to be maintained between the banks and the central bank.

Given the limitations on certain knowledge analysed by Keynes, society inevitably relies on conventional knowledge, including states of confidence, as a basis for decisionmaking. Indeed both institutional structure (including the institution of money) and social conventions provide the foundation for economic activity. A social convention »is a particular instance of an institutional rule" (Hodgson 2006: 2) which is normally, but not inevitably, followed. At the level of knowledge, just as market valuation of assets relies heavily on social convention, the degree of confidence in that valuation itself is a social convention. But new evidence to which markets are receptive, including the judgment of market leaders, may bring about a shift in conventional valuations and the state of confidence. While fractional reserve banking makes banks vulnerable to shifts in confidence, long experience of banking and the regulating and protecting role of central banks supports the conventional confidence that bank liabilities will continue to have money characteristics. But any experience which challenges that confidence threatens the banking system.

\subsection{Post-Keynesian approach to banking regulation}

The post-Keynesian approach to banking regulation rests on this understanding of banking as being built on a foundation of social convention on the one hand and involving inevitable tensions, especially between the banks and the central bank, on the other. Because of these tensions, the foundational social conventions are vulnerable. Banking regulation therefore 
needs to address these tensions and aim to keep them in reasonable balance in order for banks to perform their societal role. ${ }^{5}$

Ultimately the aim of reform of banking regulation should be to ensure the stability of the banking system in such a way as to help to restore its functionality. This involves maintaining confidence in the liabilities of the banks so that they continue to perform money functions. It also requires banks having the capacity to create credit to promote economic growth. But with increasingly complex financial markets the mainstream view of what promotes growth changed to include the promotion of competitive financial markets themselves as a means of ensuring the optimal amount of credit to finance real activity, at the lowest cost. But while mainstream analysis has seen the increasing power of financial markets in this positive light, post-Keynesians have long identified the scope for financial and economic destabilisation which financial liberalisation brings (see for example Arestis/Demetriades 1997). While mainstream analysis sees competition as stabilising, postKeynesians (influenced particularly by Minsky I982 and 1986) focus on the inherent cyclical instability of the financial sector. Taking this as the norm, post-Keynesians see the role of the state as taking the macro view and acting to reduce the amplitude, and thus social cost, of instability.

In the wake of the crisis the notion of macroprudential regulation, which addresses systemic instability, has increasingly entered the discourse on regulatory reform, under the leadership of the BIS. This is a notable development in thinking, and accords with Minskyan analysis by addressing, not only interconnectedness of portfolios, but also the cyclical fluctuations of market sentiment and leverage. As Borio (2010: 2) explains,

"[i] t means following a top-down approach, working out the desirable safety standard for the system as a whole and, from there, deriving that of the individual institutions within it. It means taking explicitly into account the fact that drivers of risk depend on the collective behaviour of financial institutions (are sendogenous ) « (emphasis in original).

The distinctive post-Keynesian approach to macroprudential regulation is that involves much more than altering incentives and constraints, but rather challenges the »essential structures, motivations, and practices of finance (Guttmann 20IO: 33). In other words, thinking of regulation in the same terms as the French Regulation approach, it involves much more than simply altering formal regulations. Indeed great care has to be taken over changing formal regulations since the consequential changes in practices and products may create new sources of instability. We saw this in the growth of securitisation and banks' activity in derivatives markets as a response to the introduction of capital adequacy requirements.

The biological metaphor has been usefully employed to analyse structures which would promote stability in the financial sector. Herbert Simon was a strong exponent of the idea

5 In the interests of promoting social cohesion, the central bank also needs to address the distributional consequences of its interest rate policy, both regarding different income classes and different regions. 
of decomposable systems which limit the scope for transmission of instability from one subsystem to the next.

"Simon himself strongly emphasized [...] that the twin notions of interdependence and decomposability related to the process of division of knowledge, were not only a necessary complement to his theory of bounded rationality, human problem solving and organizational behavior, but a sort of general unifying principle underlying all viable organized systems: human, biological or artificial« (Egidi/Marengo 2002:3-4).

More recently, Haldane (2009) has employed network theory to analyse the increasing scope for systemic risk in financial systems because of their increasing homogeneity and complexity. Haldane and May (20II) have taken further the parallels with ecological systems in order to make the case for regulatory change designed to reduce systemic risk by imposing higher capital requirements on potential >risk-spreading` institutions and by increasing diversity of portfolios between different types of institution. Financial sector segmentation, which would reverse some of the I980s process of deregulation and therefore be seen by some as reducing market efficiency, would rather shift the balance back towards stability.

But strong social structures also require social conventions which encourage motivations and practices which will ensure functionality. To promote a change in banking culture is not an easy requirement, since social conventions need to build on history, and the history of sound banking has been forgotten over the last thirty years. Nevertheless, if this is what is required, it needs to be addressed in the reform debate. If confidence is not the outcome of rational calculation, then it requires more than a change in formal regulation. Aside from the Free Banking advocacy of state withdrawal from special bank regulation, the change in formal regulation which takes most seriously the rational calculation view is the argument for narrow banking, outlined above. This focus on the payment function of bank liabilities to the exclusion of the credit creation function whereby new money is also created does not address the functionality of the asset side of the balance sheet. As a result bank functionality on both sides of the balance sheet would be so constrained that customers would be diverted elsewhere for their money and credit needs. Shadow banks might meet these needs but, not being regulated as banks, they would therefore actually increase the risk of financial crisis again.

Because of the emphasis we have placed on addressing motivations and practices, as well as structures, we turn now to consider the particular issue of moral hazard and how that can be understood and addressed by post-Keynesian theory.

\subsection{Moral hazard in post-Keynesian theory}

Based on the view that economics is a moral science, post-Keynesian analysis understands morality in a social rather than individualistic sense. Moral hazard can be thought of as opportunism with respect to some generalised form of social contract, i.e. the risk that some institution or group may be motivated to act against the public interest. By social contract is meant adherence to the social conventions which underpin the economy and society more 
generally. These conventions can be thought of as moral if they promote some ethical principle such as social justice. To the extent that banking regulation addresses morality, therefore, it should support social conventions which promote ethical principles and discourage the flouting of such conventions. To the extent that a stable social structure itself is built on ethical principles, such conventions are an absolute necessity for regulatory reform.

An ethical principle on which economic relations in general depend is trustworthiness, on the part of individuals and institutions. Hughes (20II) builds a highly useful conceptual framework for understanding trust, with application to money and banking. He demonstrates how the importance of trust follows from the pervasiveness of uncertainty and the resulting limits on calculative rationality. In the credit rationing literature, moral hazard in the form of borrowers opportunistically concealing information about their default risk causes uncertainty on the part of banks, which then lend on imperfect information and (rational) trust. Borrowers violate trust by taking on higher risk than agreed with the lender, but this is rationally allowed for by banks. From a post-Keynesian perspective however complete objective risk measures are not available to be concealed, so that the need for trust in borrower-lender relations is inevitable. Banks do use objective measures such as credit-scoring, but post-Keynesian theory shows these measures to be inadequate in the absence, even in principle, of ,true risk. This was evident in the face of the structural change which occurred with the crisis.

More generally, while the legal system helps to promote trustworthy behaviour, so much of economic behaviour goes beyond formal fully-specified contracts that society depends on trustworthiness, both for day-to-day dealings among individuals and within organisations (including financial institutions) and for longer-term conventional expectations about the behaviour of banks and the central bank. It involves a recognition of the mutual interdependence of the different parts of any social structure. The broad notion of moral hazard therefore is the risk of opportunistic behaviour which undermines the social structure.

Morals in a social sense are relational, so that the post-Keynesian notion of moral hazard is also relational. We have focused so far on the interdependence between banks and central banks. We have seen that Chick's stages of banking development theory shows banks to have evolved as agents of the state in the provision of money. This relationship developed with banks enjoying the privilege of being able to expand their balance sheets on the basis of fractional reserve banking, supported by the lender-of-last-resort facility. But in return the banks undertook to be subject to special regulation, supervision and monitoring to limit the need for the facility.

The mainstream discourse on moral hazard has focused on only one side of this sdeal, pointing to the increased risk taken on by the banks. But we need to consider also the other side of the deal, the behaviour of central banks and government. ${ }^{6}$ With globalisation of finance, the 'gentleman's agreement approach to bank regulation was replaced by formal regulation and a reduced capacity for informal enforcement of prudential conventions in banking. But then, from the I970s, the banks successfully put political pressure on governments to deregulate financial markets, to give banks more opportunities for profits,

6 This argument in particular has benefited from private conversation with Victoria Chick. 
which as we have seen ultimately led to the crisis. Central banks could do little to exert the hold on the banks that they had had under the original `deal; capital adequacy requirements were part of the problem rather than the solution.

But then the possibility arose that central banks too might not honour the deak, when they did not invoke the lender-of-last-resort facility. They did so in due course. But confidence in the deal has been eroded on both sides and central banks are actively considering mechanisms for allowing bank failures in the future. As a result, confidence in the banking system remains fragile and bank functionality is accordingly under increased threat. Governments are chiding banks for not expanding credit more rapidly, while banks are understandably cautious about exposing themselves to increased risk in the face of fiscal austerity and uncertainty about the future behaviour of central banks. If moral hazard refers to the flouting of social conventions which have ensured systemic stability then governments and central banks too have been party to it.

The other important relations of trust, and therefore moral hazard, are between central banks and banks on the one hand and bank customers on the other. Customers treated bank deposits as money in large part because they had confidence that central banks would support commercial banks. The experience of the banking crisis introduced a public concern, which was previously absent, with the reliability of central bank support for commercial banks. Even though central banks did act to meet this new concern, the spectre had been raised of the possibility of the central bank not ensuring the supply of bank liabilities as a reliable means of payment and store of value.

Recognition of mutual interdependence also broke down between banks and their customers, not just in terms of provision of a stable form of money, but also in terms of financial services, in particular credit dealings. Thus banks have behaved opportunistically in providing mortgages and credit cards to customers with a high risk of default. This behaviour is explained partly by over-confidence on the part of banks in ever-rising asset prices (and therefore the underestimation of default risk) where objective valuations were not available. This may be more a failing of knowledge than a moral hazard. But it does reflect changing bank practices which were encouraged by prospects for increased profits and which did not represent due care of customers' interests. At the same time, customers themselves may have raised moral hazard by excessive borrowing, but here the defence on knowledge grounds is more reasonable.

\subsection{Post-Keynesian policy to address moral hazard}

The problem to be addressed is the need to rebuild an understanding of mutual interdependence and thus to create a climate of confidence between banks, central banks and the nonbank public. A post-Keynesian approach to regulation looks to structures, motivations and practices in an effort to address this problem.

It has been suggested that great care needs to be taken over the introduction of regulatory restrictions which are likely to have unintended consequences. Any such restrictions need to be introduced against a backdrop of efforts to change the culture of banking to make it 
more functional. But some may be addressed to moral hazard in the narrow mainstream sense, restricting opportunities for taking on excessive risk in a relatively straightforward way. ${ }^{7}$ This approach for example supports regulation which prohibits any institutions with a retail banking license engaging in particular activities, such as proprietary trading as proposed in the USA. Second, it could support simple regulations restricting the composition of assets, such as liquidity ratios. Third, it could support risk-reducing rules on the terms and availability of mortgage and credit-card lending.

These ideas are relatively uncontroversial. They refer to restoring aspects of the banks' undertakings to the central bank and to customers in exchange for the facility to create credit. But the earlier discussion above draws attention to the central banks' side of the deal, which includes not only enforcement of such regulations, but also the lender-of-last-resort facility. The post-Keynesian argument is that, if confidence is to be restored to banking, then central banks need to reassert their undertaking to provide the facility in case enforcement of regulations proves insufficient to prevent a liquidity crisis for a bank. Given that a bank can face a liquidity crisis as a result of a change in market sentiment towards it, and for that liquidity crisis to turn into a solvency crisis, it is important for market sentiment to be reassured, not least to prevent contagion to other banks. If the negative market sentiment is justified for an individual bank however, it is the role of the central bank to address underlying problems, but not at the moment of crisis.

The common concern is with the potential scale of such liquidity provision if the bank in crisis is very large. The size of banks is due partly to the development of universal banking, such that traditional retail banking forms only part of a bank's activities. But the main concern should be with the fact that universal banks involve much higher risk-taking than retail banks, increasing the potential for a liquidity crisis. If the lender-of-last-resort facility were restricted to retail banking, detached in some way from other types of banking ${ }^{8}$, then the call on the facility would be that much less. But retail banks can still be very large; we discussed above the tendency of retail banking to concentrate for reasons of confidence. However, if bank bail-outs were to pose a problem of cost, as in the current crisis, a solution would be provided by a global insurance fund or the proceeds of a Tobin tax. Such a tax has further justification in that it would discourage, at the margin, the kind of speculative capital flows which can cause financial instability (see Ul Haq/Kaul/Grunberg 1996).

To introduce a separation between retail banking and other forms of banking would be consistent with the argument for industry segmentation which follows from the SimonHaldane analysis. Systemic risk would be reduced if portfolios were less interconnected. But of course interconnectedness of portfolios in the rest of the financial system would still pose systemic risks unless there were further segmentation. Systemic risk also follows, as we have discussed, from the interconnectedness of knowledge. Confidence or lack of confidence

7 The emphasis is on relatively‘; in the current complex financial sector any regulatory change raises complex issues.

8 This detachment could take a range of forms, from arms-length within one organisation through to complete organisational separation. 
in financial institutions is based on a social convention, which builds historically on long experience which promotes trust in spite of uncertainty. Similarly, in the shorter run, market valuations under uncertainty have a strong socio-conventional element, driving market sentiment in both positive and negative directions. There therefore seems to be a need for some kind of broad regulation to address the broad form of moral hazard which threatens the foundation of a functional banking system.

Broad regulation in this light could include the following strategies. These strategies are challenging to say the least, given the huge complexity of the system. Nevertheless, if the state is to perform its moral function in overseeing the financial system and ensuring its functionality, then these are the kinds of strategies which need to be discussed.

First, active efforts can be made by the central bank to identify undue swings in market sentiment and to counter them. This requires close dealings on the ground with market players in order to pick up quickly any change in sentiment. In the absence of true market valuations as a benchmark, it is the duty of the central bank to take the macro view, but to inform this view with good micro-level knowledge. Indeed Davidson (2002: 195-6; 253-5) argues in favour of the authorities accepting their responsibility to calm market sentiment by acting as a market-maker and to provide whatever liquidity is required. This in turn requires a change in emphasis away from inflation targeting towards financial stability (which should in fact bring along with it monetary stability). ${ }^{9}$ Reform of formal regulation may play an important part in this, such as implementing speed limits to hold back market upswings (Borio 20IO: 5-6). But there is also scope for moral suasion. In a framework which does not see a duality between rational calculation and sentiment (including moral sentiment), but rather emphasises the (necessarily) conventional elements of knowledge, the apparently old-fashioned notion of moral suasion still makes sense.

Second, moral suasion can be employed also to promote a change in culture in banks and other financial institutions. This has a much better chance of success than regulatory restrictions which invite evasive practices. As Frey and Benz (2005) argued in the wake of the Enron scandal, there is scope for the private sector to learn from public sector example. This can be aided by more active monitoring and supervision of banks, including their governance structures, as well as increased attention to the governance of the monetary authorities themselves. It can also be aided by active government support for banking with the kind of culture and practices which make banks functional, such as the social, cooperative and ethical banks which have maintained and enhanced confidence in the market during the crisis. ${ }^{10}$ Even more, where governments have taken on ownership, or part-ownership, of banks as a crisis measure, there is an ideal opportunity, not only for government to internalise the kind of knowledge of banking which is so difficult to achieve from the outside, but also to establish the kind of culture it would like to promote.

9 This change in emphasis has been occurring out of necessity in the shadow of the banking crisis. But many central banks continue formally to be tied to government inflation targets.

Io This argument is reinforced by the fact that demutualisation allowed a change in culture and practices which fuelled the crisis. 


\section{Conclusion}

We have seen that an understanding of money and banking in terms of individualistic rational calculation where full information is in principle accessible pitches the discussion of bank regulation in terms of altering incentives and constraints, if not in terms of withdrawal from special bank regulation altogether. Bank functionality is seen as being no different from that of any other financial intermediary, and is tied to the free operation of competitive markets.

But the discussion changes if banks are understood in terms of their evolution in relation to society and to the monetary authorities, where knowledge is held with varying degrees of uncertainty. Banking is at its most functional, in providing a means of payment and credit/money creation, when there are good relations between banks, central banks and customers which reflect an understanding of their interdependence. With the banking crisis, these relations have broken down, eroding the social structure underpinning the economy. Policy therefore needs to be addressed to re-establishing relations based on a build-up over time of a mutual sense of confidence.

To address this issue, as in changing banking culture, poses massive challenges, but is nevertheless necessary for restoring the functionality of banks. The rationalist mainstream framework discourages such an approach on the grounds that bank behaviour is governed by the logic of rational self-interested profit maximisation. Anything else by definition is deemed irrational. Morals do not enter into the analysis, making the term ımoral hazard highly misleading.

But post-Keynesian theory does not make such a dualistic distinction between rationality and irrationality, or between rationality and morals. Rather reason is understood as integrated with sentiment, including moral sentiment, given the socio-conventional foundation for knowledge and behaviour (Dow 20II). It is argued therefore that bank behaviour cannot be separated from the requirements for a stable financial system in order for all to benefit; the crisis was the consequence of thinking that such separation was feasible. A stable financial system requires that banks and central banks honour the traditional arrangement whereby banks are supported by the lender-of-last-resort facility to provide the economy's money and credit and enjoy the benefits this brings them in increased profits (while at the same time honouring the traditional relationships with their customers) in exchange for acceding to a central bank view of acceptable bank structures and practices. The broad form of moral hazard to be addressed is that the social structure, and banks' and central banks' part in it, is eroded.

\section{References}

Akerlof, G., Shiller, R. (2009): Animal Spirits.Princeton: Princeton University Press.

Arestis, P., Demetriades, O.P. (1997): Financial development and economic growth: Assessing the evidence, in: Economic Journal, IO7(442), 783-99.

Arrow, K.J. (1963): Uncertainty and the welfare economics of medical care, in: American Economic Review, 53(5), 94I-69. 
Bibow, J. (2009): Keynes on Monetary Policy, Finance and Uncertainty: Liquidity Preference Theory and the Global Financial Crisis, London: Routledge.

Borio, C. (2010): Implementing a Macroprudential Framework: Blending Boldness and Realism, Basle: BIS.

Calomiris, C.W. (1998): The IMF's imprudent role as lender of last resort, in: Cato Journal, I7(3), $275-94$.

Calomiris, C.W. (2009): The subprime turmoil: What's old, what's new, and what's next, in: Journal of Structured Finance, I5 (Spring), 6-52.

Chick, V. (1986/1992): The evolution of the banking system and the theory of saving, investment and interest, in: Economies et Sociétés, serie Monnaie et Production no. 3, III-26, reprinted in: Arestis, P., Dow, S.C. (eds.): On Money, Method and Keynes, London: Macmillan.

Chick, V. (2008): Could the crisis at Northern Rock have been predicted? An evolutionary approach, in: Contributions to Political Economy, 27(I), II5-I24.

Cowen, T., Kroszner, R. (1987): The development of New Monetary Economics, in: Journal of Political Economy, 95(3), 567-90.

Davidson, P. (2002): Financial Markets, Money and the Real World. Cheltenham: Edward Elgar.

De Bondt, G.J. (200o): Financial Structure and Monetary Transmission in Europe, Cheltenham: Edward Elgar.

Dembe, A.E., Boden, L.I. (2000): Moral hazard: A question of morality?, in: New Solutions, IO(3), 257-79.

Dillard, D. (1987): Money as an institution of capitalism, in: Journal of Economic Issues, 2I(4), $1623-47$.

Dow, S.C. (2008): Mainstream methodology, financial markets and global political economy, in: Contributions to Political Economy, 27, 13-29.

Dow, S.C. (20II): Cognition, market sentiment and financial instability, in: Cambridge Journal of Economics, 35(2), 233-50.

Dow, S.C. (forthcoming): Economics and moral sentiments: The case of moral hazard, in: Neves, V., Caldas, J.C. (eds.), Facts, Values and Objectivit, London: Routledge.

Dowd, K. (2009): Moral hazard and the financial crisis, in: Cato Journal, 29(I), I42-66.

Egidi, M., Marengo, L. (2002): Cognition, institutions, near decomposability: Rethinking Herbert Simon's contribution, CEEL Working Papers 0206, published in: Augier, M., March, J.J. (eds.) (2004), Models of A Man: Essays in Memory of Herbert A. Simon, Part III: Modeling Systems, Cambridge MA: MIT Press.

Frey, B.S., Benz, M. (2005): Can private learn from public governance?, in: Economic Journal, II5(507), F377-396.

Gowland, D. (1990): The Regulation of Financial Markets in the I9gos, Cheltenham: Edward Elgar.

Guttmann, R. (20IO): Re-regulating finance, paper presented to the FMM Conference, Berlin, 29-30 October 2010.

Haldane, A. (2009): Rethinking the Financial Network, http://www.bankofengland.co.uk/ publications/speeches/2009/speech386.pdf

Haldane, A., May, R.M. (20II): Systemic risk in banking ecosystems, in: Nature, 20 January, $469,35 \mathrm{I}-5$. 
Hodgson, G.M. (2006): What are institutions?, in: Journal of Economic Issues, 40(I), I-25.

Hughes, P. (20II): Trust: Economic Notions and its Role in Money and Banking, University of Stirling PhD thesis.

Ingham, G. (2004): The Nature of Money, Cambridge: Polity Press.

Kay, J. (2009): Narrow Banking: The Reform of Banking Regulation, London: CSFI.

King, M. (2009): Speech to Scottish business organisations, Edinburgh, URL: www.bankofengland. co.uk/publications/speeches/2009/speech406.pdf

Kotlikoff, L.J. (2010): Jimmy Stewart is Dead - Ending the World's Ongoing Financial Plague with Limited Purpose Banking, New York: John Wiley and Sons.

Merton, R.C. (1993): Operation and regulation in financial intermediation: A functional perspective, in: Englund, P. (ed.), Operation and regulation of financial markets, Stockholm: Economic Council.

Minsky, H.P. (1982): Inflation, Recession and Economic Policy, Brighton: Wheatsheaf.

Minsky, H.P. (1986): Stabilizing an Unstable Economy, New Haven: Yale University Press.

Pauly, M.V. (1968): The economics of moral hazard: Comment, in: American Economic Review, $53(5), 53 \mathrm{I}-7$.

Stiglitz, J., Weiss, M. (198I): Credit rationing in markets with imperfect competition, in: American Economic Review, 7I, 22-44.

Studart, R. (1995): Saving, financial markets and economic development: Theory and lessons from Brazil, in: Arestis, P., Chick. V. (eds.), Finance, Development and Structural Change: Post-Keynesian Perspectives, Cheltenham: Edward Elgar.

Ul Haq, M., Kaul, I., and Grunberg, I. (eds.) (1996): The Tobin Tax: Coping with Financial Volatility, Oxford: Oxford University Press. 